\title{
The Role of International Financing Coordination in Enhancing the Competitive Advantages of Nations
}

\author{
Asst. Prof. Dr. Müge Burcu Özdemir (Istanbul Aydın University, Turkey) \\ Asst. Prof. Dr. Beyhan Hilal Yaslıdağ (Istanbul Aydın University, Turkey)
}

\begin{abstract}
In this study international finance and its coordination are discussed by considering the factors determining competitiveness and competitiveness. The effects of international finance coordination are analyzed. Afterward, possible problems and solutions evaluated. In the final part, the effect of combining various forms of international financing and assistance in harmony is coordinating, on the competitiveness of countries using financing are evaluated. The use and effects of the resources obtained by utilizing international financial resources have been examined by considering the conditions of competition. Competitiveness and the factors that determine competitiveness are discussed and international finance and international financing resources are discussed. Then, the institutions that have effects on the coordination of international finance are examined. This is a review article, so it is aimed to emphasize the importance of international financing coordination. To ensure that the financial aids given are sent to the countries that use the aids following their intended use, to increase the amount of international finance and funds, to distribute the burden of credit usage costs among developed countries and institutions according to certain criteria, to ensure that the repayment conditions of the credits are easy and applicable for the country using the credit, and to ensure that the information flow between the countries providing and using the credit is continuous and regular can be considered the important subjects of the international financing coordination.
\end{abstract}

\section{Introduction}

In today's world, competitive economies benefit from international financing resources to achieve faster development and to position themselves as attractive for foreign investments. Especially developed countries provide financing to developing countries and then coordinate these finances themselves or through certain institutions. With the ever-increasing interest and influence of developed countries in providing financing to developing countries, it ensures the development of the relevant financial institutions as a result of the need for international financing. Thus, developed countries coordinate these finances themselves or through certain institutions. When analyzed in terms of macroeconomic data and values, the effects of international financing resources on macro values become more important, especially when the competitive factor is included in the business. Developing economies are directed to use their investments effectively, through the coordination of international finance. Thus, waste of resources and ineffective use is prevented. With the coordination of international finance, these investments are transformed into production and employment, so countries using international finance can increase their competitive advantage.

Most of the developing countries are in search of resources to finance the necessary investments to take their development processes one step further. In particular, liberalization, macroeconomic stability, and restructuring are key issues in development processes (IMF, 2000).

Investment opportunities will increase due to the liberalization of the economy and the establishment of a structure that operates with free-market dynamics instead of a single center. This situation will have an effect that will accelerate the economies with positive reflections such as an increase in employment (Ağayev, 2012).

It is important whether the external financings used for this purpose are used in line with the determined targets. Some developing countries can effectively direct the external financing they use and reach their targets more easily. Some other countries waste the resources they have obtained through misuse. Even if the initial conditions, set development goals and planned reforms are the same, the results differ for developing countries (Bal, 2003).

\section{International Finance Management and Coordination}

International finance management and coordination can be defined as the processes of determining targets, expressing opinions on planning and project selection, deciding on the amount of financing, ensuring healthy communication between the parties, and evaluating whether external financing is used effectively by its purpose (Özkurt Çokgüngör, 2010).

The type of investment that is frequently emphasized in the opinions that developing countries can support their development goals through the use of various external financing is "Foreign Direct Investment". Foreign Direct Investments have an accelerating effect on the growth of developing countries' economies (Bal, 2003). 
In investment decisions, besides factors such as the richness of the target country in terms of factor endowment, the vitality of its domestic demand, the sufficient production facilities, and the political stability of the country are also important (Alagöz et al. 2008).

According to Stiglitz (1999), the existence of stable economies and reliable governments makes the country more attractive for foreign investment.

In addition, according to Stiglitz (1999), supporting entrepreneurship also depends on sufficient capital. Few developing countries have this amount of capital. Local organizations that have difficulty in extracting value despite being in control of an economic asset will of course seek other resources that can be more effective.

Despite the different development levels and economic powers of the countries, the motivation of being together at the international level and acting in order has continued for many years. The desire of countries to cooperate sustainably is a reasonable approach (Özdemir, 2011).

\section{Objectives of International Finance Coordination}

The goal, which can be described as the major among the goals of international financing coordination, is to increase the effectiveness of finance, which is a goal that can be achieved in the long term (Özkurt Çokgüngör, 2010).

Other goals are as follows (Özkurt Çokgüngör, 2010):

- To ensure that the loans extended are delivered to the countries using the loan under the usage targets,

- Increasing the amount of international financing and credits to be made available, avoiding double use (duplication) in the financing provided,

- To distribute the burden of the costs arising from the use of finance to developed countries according to certain criteria,

- The repayment terms of the financings are easy and applicable in terms of the country using the credit,

- Goals such as ensuring a continuous and regular flow of information between the country providing and using the financing can be counted.

\section{The Role of International Institutions in International Finance Coordination}

Each developing country has a unique export financing need and accordingly a method of providing external financing. (Özdemir, 2011)

The existence of institutions that will make the communication between various export financing institutions and developing countries work healthily and undertake the supervisory mission was needed. GATT, WTO, and OECD are the most important of these organizations (agreements), which are classified under two headings as international initiatives and organizations providing regional cooperation, in terms of external financing (Özdemir, 2011).

\subsection{General Agreement on Tariffs and Trade (GATT)}

The General Agreement on Tariffs and Trade, whose primary purpose is the liberalization of international trade and which will be briefly referred to as GATT in this study, has served as an important catalyst in the elimination of protectionist policies. It was established in 1947 with the signing of 23 countries (WTO).

GATT paved the way for the establishment of the World Trade Organization and is an important milestone in world trade in terms of protecting and controlling the integrity of multilateral agreements and determining the necessary sanctions (Irwin, 1995).

\subsection{World Trade Organization (WTO)}

The World Trade Organization, which is the continuation of the GATT, was established in 1995 by the countries that were party to the Uruguay Negotiations within the General Agreement on Tariffs and Trade (Irwin, 1995).

The World Trade Organization covers intellectual property rights as well as trade in goods and services (WTO).

Although the World Trade Organization aimed to bring a certain functionality to the world trade system and to coordinate the system, the principles of GATT are at the core of the organization. Especially when it comes to commercial disputes, the existence of an authority or an organization in an arbitration position was needed, and the World Trade Organization was established for this purpose (WTO).

\subsection{Organization for Economic Development and Cooperation (OECD)}

The OECD, whose members are mostly members of the European Union, has a member country profile consisting of developed and developing countries (OECD) 
When the main objectives of the OECD are examined, major macroeconomic issues such as economic growth, financial stability, trade and investment, technology, innovation, entrepreneurship, fighting against poverty, and increasing welfare stand out (OECD)

\section{Types of International Finance Coordination}

\subsection{Coordination of International Financing by the Financier Country}

It may be the case that a developing country's government agencies have weak control over the demands of certain investment sectors for various resources. In such a case, since it will not be possible to provide financial coordination, it is more appropriate for the receiving country to coordinate itself. With this kind of coordination, the country that uses the financing can better control its economy, public investments, domestic and international financing needs of the investment and can provide better solutions against possible problems (Claessen,1991).

\subsection{Coordination with an International Financing Institution}

The fact that developed countries want to assist an international organization because they cannot undertake the financing to be made to any developing country due to various economic and political reasons makes this type of coordination attractive (Claessen,1991).

The World Bank, the International Development Association (IDA), and the United Nations affiliates have been successful in developing aid coordination. International organizations generally collect the funds and funding sources they provide in various forms from member countries in different ways. Despite this, they are channeling aid to underdeveloped countries by following certain aid policies, arranging aid conditions according to them (WORLD BANK).

\subsection{Coordination of Financing from Various Sources to a Country}

Receiving and coordinating assistance from various sources takes two forms in practice. The "consortiums" formed with the start of multilateral financial aids are the first form. The other is "advisory groups". A consortium is an institution in which a joint financial aid program is prepared by the donors, by preparing the ground for an agreement on the amount of international financing necessary for the implementation of the recipients' development programs between the countries that will make the financing and the recipient countries. Advisory groups began to be established in the light of the experience gained from the World Bank's cooperation with donor countries during joint aid efforts (Teker, 2008).

\subsection{Coordination of Bilateral Financial Aid Policy between Aiding Countries and Organizations}

The Development Assistance Committee (DAC), an OECD organization, was established as an organization that responds to the financing needs of countries. It was established in 1960 within the framework of the OECD as a member of the organization or not, to implement the purpose of contributing to the economic development of the countries in the development effort of the OECD. The purpose of the DAC is to bring together the countries that provide aid to developing countries, to discuss and exchange views on aid-related issues. To this end, the DAC has undertaken the statistical measurement of incoming development assistance flows to developing countries to ensure that the responsibility for assisting is shared equally. Today, the DAC is an advisory body for countries providing capital and technical assistance to developing countries, as well as responsible for handling direct and indirect aid flows to various countries and regions (OECD).

\subsection{Coordination by Financing Countries for Major Projects}

Countries and international organizations that come together at the request of the developing country, determine how and in what amount they will meet the financing of the project, and undertake the coordination of aid called "union". Developing countries can also benefit from the competition between member states for various reasons in financing large projects. An important point about this type of aid coordination is that although it includes a higher rate of dependent aid than other types of coordination, if international organizations such as the World Bank are members, it provides advantages to the debtor country, especially in debt repayment (Naleszkiewicz, 2011).

\subsection{Regional Based Financing Coordination}

The purpose of this type of coordination is to collectively assist the development problems of developing countries in a predetermined region and accelerate regional development. The "Inter-American Committee for the Alliance for Progress" (CIAP), a subsidiary of the United States Organization for Latin America, the InterAmerican Economic and Social Council, is an example of a regional organization. Another example is "The Colombo Plan" established within the Commonwealth of Nations. The Plan is aid coordination established between the developing countries of the Far East and South Asia and the industrialized countries of the free world, based on common interests in the region (Butterfield, 2004)

\section{Competitive Advantages}

The successful realization of international financing coordination results in the effective use of financing by the receiving country. In this way, resources are not wasted and are evaluated for financing. Considering that 
developing countries generally use foreign financing for investment, production, and employment purposes, the contribution of effective foreign financing to increase the competitiveness of that country will be better understood. (Ling-Yee, 2001).

The resource advantage theory, developed by Morgan and Hunt in 1995, can be explained as the identification of the basic skills and resources of the businesses and thus gaining competitive advantage (Hunt, 1995).

Certain criteria must be met for sustainable competitive advantage to work in terms of resource theory. The first criterion is that they create a "value" through their resources and capabilities. The second criterion is that they have resources and skills that differ from other firms (Marangoz et al. 2020).

International financing coordination is important in terms of effectively using the skills and finances of enterprises in general and increasing their competitiveness. Here, financing is provided to countries on a project basis rather than directly to companies, but governments make good sector planning and evaluate them inappropriate investments and suitable businesses.

\section{Conclusion}

In this study, the contribution of international financial coordination to the competitive structures of developing countries has been examined. Whether they evaluate the external financing they have provided by their purpose or not is an effective use issue and is also important for the country providing the financing. Even if the conditions for using foreign aid, development goals, and planned reforms are the same, the results may differ for developing countries. Therefore, the coordination of the financing used by the developing countries is an issue that should be evaluated in terms of the international economy. The role of international organizations in international financing coordination is significant. In the liberalization process of trade, which started with the General Agreement on Tariffs and Trade (GATT), there was an interaction between countries not only in terms of goods and services but also in terms of financing. With the World Trade Organization established afterward, the world trade system gained a certain functionality.

The OECD, which deals with major macroeconomic issues such as financial stability, trade, and investment, technology, innovation, entrepreneurship, poverty alleviation, and welfare increase, plays a role in increasing the competitive advantages of developing countries.

Coordination of international financing by the financier country, coordination with an international financing institution, coordination of financing from various sources to a country, coordination of bilateral financial aid policy between aiding countries and organizations, coordination by financing countries for major projects, regional-based financing coordination are types of international financing coordination

As a result, it can be said that the way for a developing country to use the financing coordination it has provided without waste is through effective coordination. Thus, the competitiveness of countries will be positively affected.

\section{References}

- International Monetary Fund, 2000, Transition Economies: An IMF Perspective on Progress and Prospects, https://www.imf.org/external/np/exr/ib/2000/110300.htm

- Ağayev, 2012. Geçiş Ekonomilerinde Liberalleşmenin Ekonomik Büyüme Üzerinde Etkisi, Ç.Ü. Sosyal Bilimler Enstitüsü Dergisi, cilt 21, sayı3, 2012, p.310

- Bal, 2004. Geçiş Ekonomilerinde Ekonomik Büyüme ve Dış Finansman. Manas Üniversitesi Sosyal Bilimler Dergisi 6 (12) , p.159, 160

- Özkurt Çokgüngör, 2010, Uluslararası Finansman, İstanbul Üniversitesi Açık Ve Uzaktan Eğitim Fakültesi, p.7) http://auzefkitap.istanbul.edu.tr/kitap/disticaret_ue/uluslararasifinansman.pdf

- Alagöz, Erdoğan ve Topallı 2008. Foreign Direct Investment and Economic Growth: Evidence from Turkey 1992-2007. Gaziantep University Journal of Social Sciences , 7 (1) , p.80

- Stiglitz, 1999, Whither Reform? Ten Years Of The Transition, World Bank Annual Bank Conference On Development Economics, Washington, D.C.April 28-30 p. 6, 12

- Özdemir, 2011, İhracat Finansmanı Alanında Uluslararası Girişimler ve İşbirliği İhtiyacı . İstanbul Üniversitesi İktisat Fakültesi Mecmuas1, 47 (1-4), p. 1, 245,246

- World Trade Organisation, https://www.wto.org/english/tratop_e/gatt_e/gatt_e.htm

- Irwin, 1995 The GATT in Historical Perspective, The American Economic Review Vol. 85, No. 2, Papers and Proceedings of the Hundredth and Seventh Annual Meeting of the American Economic Association Washington, DC, January 6-8, p 323

- $\quad$ www.oecd.org

- Claessen,1991, Alternative Forms of External Finance, Ollcy Research, Working Papers, International Economics Department The World Bank December 1991 
- https://ida.worldbank.org/

- Teker, 2008. Sağlik Sektöründe Proje Finansman Modelleri: Türkiye İçin Bir Model Önerisi ve Bir Hastane Projesinin Fizibilite Analizi. Muhasebe ve Finansman Dergisi , (37) , 1-18

- https://www.oecd.org/dac/development-assistance-committee/

- Naleszkiewicz, V . (2011). Sovyet Rusya'da Sosyal Sigortaların Finansmanı ve Kapsamı .Journal of Social Policy Conferences ,0 (19), 299-322 p.

- Butterfield, 2004, U.S. Development Aid-an Historic First: Achievements and Failures in the Twentieth Century. Westport, CT: Praeger. P. 81

- $\quad$ Ling-yee,\& Ogunmokun, 2001. "Effect Of Export Financing Resources And Supply-Chain Skills On Export Competitive Advantages: Implications For Superior Export Performance," Journal of World Business, Elsevier, vol. 36(3), pages 260-279, October. p. 261

- Hunt and Morgan, 1995. The Comparative Advantage Theory of Competition. Journal of Marketing, 59(2), 1-15.

- İnak Özberk ,Marangoz,2020. Sürdürülebilir Rekabet Avantajı Sağlamada Kaynak Avantaj1 Teorisi ve Pazar Yönlülük Yaklaşımı . Yönetim ve Ekonomi Dergisi , 27 (1) , 69-89 . DOI: 10.18657/yonveek.539379 p.74 